\title{
Aminolysis of Methylbenzene Sulfinate: Definitive Evidence for a Stepwise Mechanism
}

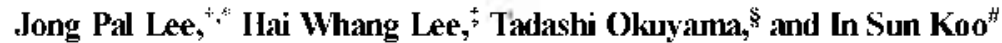

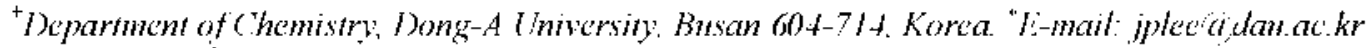 \\ $\because$ Department of Chemistry: Inha University: Incheon $402-751$. Korea \\ \$Iniversity of Iyogo. Kamigori, Iyogo 678-1297. Japan

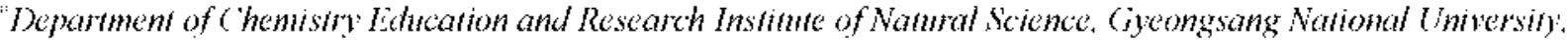 \\ Iinin 600-701. Korea \\ Recerved June 11, 200\%. Aceepted Jil) 1, 2009
}

Key Words: Methylbenzene sulfinate, Stepwise mechanism, Hyperval ent intermediate

There are some reports on the nucleophilic substitution reactions of sulfinate esters. The reaction behavior of these compounds shows with or without a hypervalent intermediate ria the addition elimination or a concerted $S: 2$ type mechanism. ${ }^{1-2}$ For exante, the acid hydrolysis of alkyl sulfinate esters as well as cyclic sulfinates proceeds in a concerted $S, 2$ type mechanism, ${ }^{3-4}$ while the base catalyzed hydrolysis of cyclic sulfinates with a phenolic leaving group takes place through a hypervalent intermediate. ${ }^{5}$ However, there is little report on the aminolysis of sulfinate esters. So, we now examine the aminolysis and the alkaline hydrolysis of methylbenzene sulfinate for the purpose of comparison

\section{Experimental}

Mateiials. Methylbenzene sulfinate used as a substrate was of the best grade commercially avaliable. Licjuid amines were distilled from pottasium hydroxide immediately before use. $\mathrm{NaOH}$ solutions were prepared from $1 \mathrm{M}-\mathrm{NaOH}$ standard solution of Tokyo Kasei and distilled water. Doubly glass deionized water was further boiled and cooled under nitrogen before use.

Kinetic Measuements. The rates for ammolysis were measured spectrophotometrically in $\mathrm{H}_{2} \mathrm{O}$ at $25 \pm 0.1^{\circ} \mathrm{C}$ by following the decrease in absorbance due to disappearance of the substrate at wavelengths in the range of $244-280 \mathrm{~nm}$. The rate measurements were carried out using a Hewlett Packard 8452 Diode Array spectrophotometer equipped with a Shimadzu TB85 -thermo bath to keep the temperature of the reaction mixture at $25^{\circ} \mathrm{C} \pm 0.1^{\circ} \mathrm{C}$. The reaction was carred out under pseudo first order condition in which the amine concentration was at least 10 times greater than that of the substrate. The amine solutions were prepared by dissolving two equiv of free anine and one equiv, of standardized $\mathrm{HCl}$ solution to keep the $\mathrm{pH}$

Table 1. Observed rate constants $\left(h_{\text {ell }}\right)$ for the aminolysis and the alkaline hydroly sis of methy lben/ene sulfunate in $\mathrm{H}_{2} \mathrm{O}$ at $25^{\circ} \mathrm{C}$

\begin{tabular}{lll}
\hline Amine (pKa) & $\mid$ Amine $\mid \mathrm{M}$ & $10^{3} \times \mathrm{k}_{\text {ul }} / \mathrm{s}^{-1}$ \\
piperidine $(11.2)$ & $0.001 \sim 0.20$ & $3.09 \sim 33.5$ \\
chly lamime $(10.6)$ & $0.001 \sim 0.20$ & $(1.808 \sim 9.24$ \\
pipcrazinc $(9.82)$ & $0.001 \sim 0.20$ & $0.235 \sim 0.991$ \\
$\mathrm{NaOH}(15.7)$ & $0.001 \sim 0.008$ & $1+.4 \sim 117$ \\
\hline
\end{tabular}

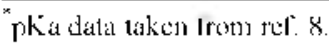

constant by makıng a self buffered solution. The amıne solution employed were piperidine $/ \mathrm{HCl}$, ethylamine/ $\mathrm{HCl}$, piperazine/ $\mathrm{HCl}$. Typically, kinetic run was initiated by injecting $30 \mu \mathrm{L}$ of $1.0 \times 10^{-2} \mathrm{M}$ stock solution of the substrate in acetonitrile into $3.0 \mathrm{~mL}$ of amine solution maintained at $25{ }^{\prime \prime} \mathrm{C} \pm 0.1$ " $\mathrm{C}$ in a cell compartment of the spectrophotometer.

\section{Results and Discussion}

The aminolysis of methylbenzene sulfinate in $\mathrm{H}_{2} \mathrm{O}$ obeyed pseudo-first order kinetics under large excess amine concentration. Pseudo first order rate constant $\left(k_{0 \mid w_{i}}\right)$ was obtaned from the slope of the plot of $\ln \left(\lambda-\lambda_{i}\right)$ is time and are listed in Table 1.

The $k_{\text {olu }}$ value increases as the basicity of amme increases, but it shows nearly constant value at higher concentration of amine. The kinetic results are illustrated graphically in Figure 1. The plots of $k_{0 b}$ is amine concentrations show the concave downward curvatures which are leveled off as the concentration of amine increases. Even though, there are some reports on the concave downward curvature in the nucleophılic substitution reactions of cyclic sufinate esters ${ }^{6}$ and carboxylate ester, ${ }^{7}$ and it is a first finding for the concave downward curvature to observe for the aminolysis of a acyclic sulfinate ester.

The nonlınear variation of rate with increasing nucleophile concentration suggests the existence of intermediate, indicatung

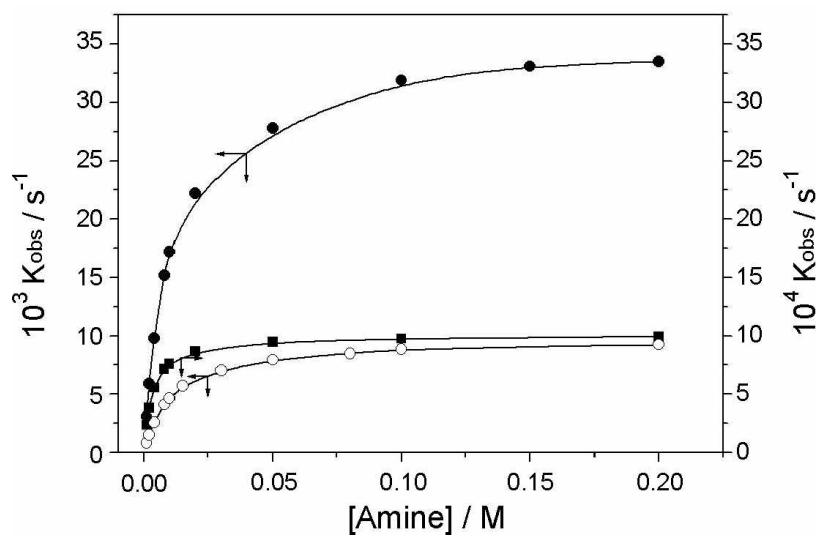

Figure 1. Plots of $k_{\text {tix }} v$ s amine concentrations for the aminoly sis of methy lbenzene sulfinate "ith piperidine $(\bullet)$. chls lamine( $)$ and piperazine(- in $\mathrm{H}_{2} \mathrm{O}$ al $25^{\circ} \mathrm{C}$. 
that the reaction proceeds via a stepwise mechanism as shown in Scheme 1.

The observed rate constant $\left(k_{\mathrm{obs}}\right)$ for two steps involving the intermediate is derived eq.l using the steady state approximation, where $[\mathrm{Nu}]$ represents the concentration of amine.

$$
k_{\mathrm{c} b: \mathrm{s}}=\mathrm{k}_{1} \mathrm{k}_{2}[\mathrm{Nu}] /\left\{\mathrm{k}_{1}[\mathrm{Nu}]+\mathrm{k}_{-1}+\mathrm{k}_{2}\right\}
$$

If the reaction proceeds in a stepwise mechanism with intermediate. the plot of $1 / k_{\mathrm{ob}} \mathrm{v} 1 / \mathrm{su}$ ) of eq. 2 which is rearranged from eq. 1 should be linear. As one can see in Figure 2, the linear plot with intercept has been obtained. The value of intercept means the rate constant for the reaction of substrate with $\mathrm{H}_{2} \mathrm{O}$ or $\mathrm{OH}^{-}$at zero concentration of amine.

$$
1 / k_{\mathrm{obs}}=1 / \mathrm{k}_{2}+\left(\mathrm{k}_{.1}+\mathrm{k}_{2}\right) / \mathrm{k}_{1} \mathrm{k}_{2} \cdot 1 /[\mathrm{Nu}]
$$

Therefore the aminolysis of methylbenzene sulfinate is proposed to proceed in a stepwise mechanism with the formation of intermediate which decays slowly to the product as shown in Scheme 1 .

To get more information on the stepwise mechanism, we have been calculated the microscopic rate constants $\mathrm{k}_{1}, \mathrm{k}_{\text {.] }}$ and $\mathrm{k}_{2}$ in Scheme 1 . The $1 / \mathrm{k}_{2}$ value can be determined by the intercept of the plot of $\mathrm{l} / \mathrm{k}_{\mathrm{obs}} \mathrm{ls} \mathrm{l} /\left[\mathrm{Nul}\right.$. The $\mathrm{k}_{\mathrm{j}}$ and $\mathrm{k}_{\mathrm{j}}$ values can be calculated by a nonlinear regression method. As shown in Table 2, the magnitude of $\mathrm{k}_{2}$ values is smaller than that of $\mathrm{k}_{-}$values for all
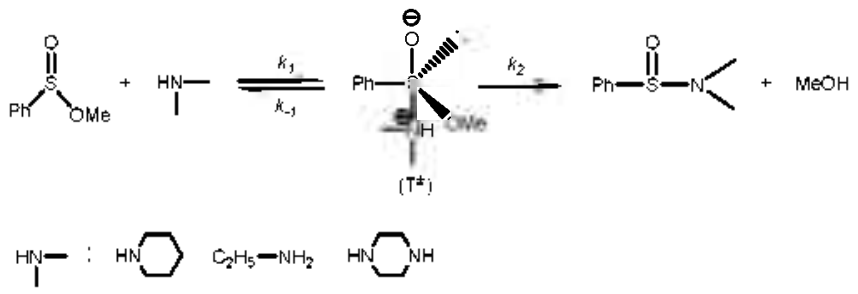

\section{Scheme 1}

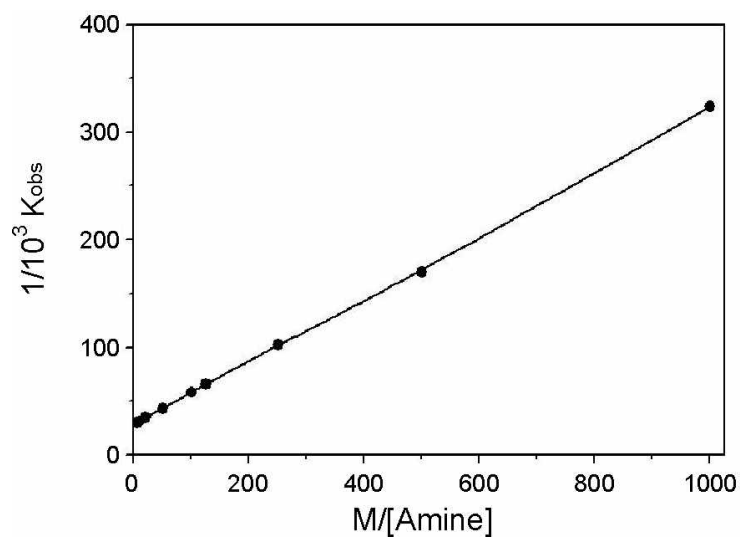

Figure 2. Plot of $1 / k_{v b s} v 1 /$ [piperidine] tor the aminolysis of methylbenzene sulfinate with piperidine in $\mathrm{H}_{2} \mathrm{O}$ at $25^{\circ} \mathrm{C}$.

Table 2. Sumnary of microscopic rate constants for the anninoly sis of methylbenzene sulfinate in $\mathrm{H}_{2} \mathrm{O}$ at $25^{\circ} \mathrm{C}$

\begin{tabular}{llllll}
\hline \multicolumn{1}{c}{ Amine } & $\mathrm{pKa}$ & $\mathrm{k}_{1} / \mathrm{M}^{-} \cdot \mathrm{s}^{-1}$ & $\mathrm{k}_{\mathrm{l}} / \mathrm{s}^{-1}$ & $\mathrm{k}_{2} / \mathrm{s}^{-1}$ & $\mathrm{k}_{1} / \mathrm{k}_{2}$ \\
\hline piperidine & 11.2 & 10.1 & $7.04 \times 10^{-\hat{2}}$ & $3.51 \times 10^{-2}$ & 0.449 \\
ethylamine & 10.6 & 2.28 & $1.50 \times 10^{-2}$ & $9.67 \times 10^{-3}$ & 1.55 \\
piperazine & 9.82 & 0.791 & $1.63 \times 10^{-3}$ & $1.00 \times 10^{-3}$ & 1.62 \\
\hline
\end{tabular}

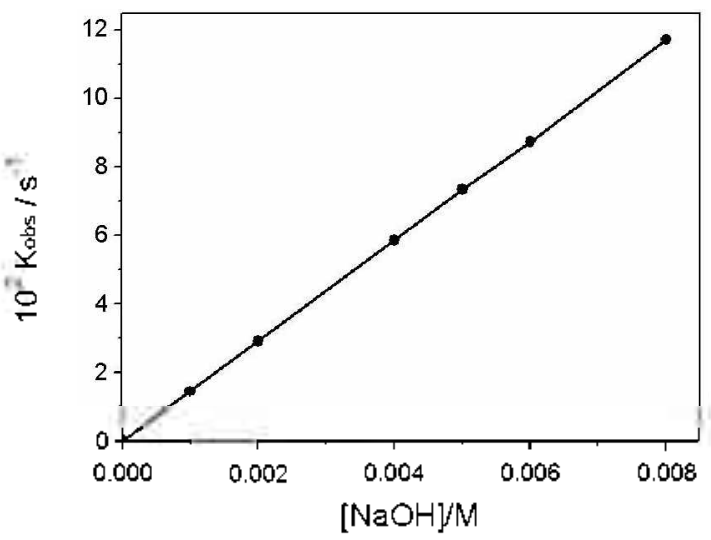

Figure 3. Plots of $k_{\text {ubs }}$ w $\mathrm{NaOH}$ concentrations for the hydrolysis of methy lbenzene sulfinate at $25^{\circ} \mathrm{C}$.

the amines studied. This results support that the aminolysis of methylbenzene sulfinate proceeds in a stepwise mechanism with rate deternining decay of the internediate. Therefore. the concave downward curvature shown in Figure 1 is definitive evidence for a stepwise mechanism for the aminolysis of sulfinate ester

However, the observed rate constants for alkaline hydrolysis of methylbenzene sulfinate are proportional to $\mathrm{NaOH}$ concentrations as shown in Fig. 3. This result means that the reaction mechanism changes as the basicity of nucleophile is much larger than that of anine employed in the present study. Although there is no definitive evidence for the formation of a loypervalent intermediate in alkaline hy'droly'sis of methylbenzene sulfinate, the transition state structure should be similar to the hypervalent intermediate. Therefor this reaction may proceed in a concerted $\mathrm{S}_{\mathrm{N}} 2$ mechanism.

\section{Summay}

We propose that the aminolysis of methylbenzene sulfinate proceeds in two steps and the concave downward curvature of the plot of $k_{\mathrm{ibs}} v s$ anine concentration is definitive evidence for a stepwise mechanism. Whereas. we can not find a hypervalent intermediate in alkaline hydroly sis.

Acknowledgments. This study was supported by research funds from Dong-A University.

\section{References}

1. Senatore, L. E.; Ciuftarine, A.; Fava; Levita, G. J. Am. Chem. Soc. $1973,95,2918$

2. (a) Najam, A. A.: Tillett. I. G. J. Chem Soc., Perkin Trans. 2 1975. 858 (b) Hwang. S. J.: Park. Y. M.: Um. I. H. Bull. Korean Chem. Soc. 2008, 29, 1911 . (c) Su, J. A.: Le, H. M.: Um, I. H. Bull. Korean Chent. Soc. 2008, 29, 1915 . (d) Lumbiny, B. J : Adlikary, K. K.; Lee, B. S.: Lee, H. W. Bull. Korech Chem. Soc. 2008, 29, 1769.

3. Okuyama, T. Nagase, S. J. Chem Soc., Pethin Trans 2 1994, 1011.

4. Okllyama, T.: Tákano, H.: Ohnishi, K.: Nagase, S.J. Org. Chem. $1994,59,472$.

5. Okuyama, T. Chem. Lett. 1995,997

6. Un, I. H.: Lee. H. W.: Park, I. Y. Tetrahedron Letters 1990, $\$ 1,8901$.

7. Koh. H. J. Lee, J. W. Lee, I. C. Can. J. Chem 1998, 76, 710

8. Tencks, W. P.; Regenstein, F. Handbook of Biochentistry Selected Data for Molecular Biology Sober, H. A., Ed.: The Chemical Rubber: Cleveland, 1968. 